\title{
Married Women Labor Supply Decision in Malaysia
}

\author{
Rahmah Ismail $^{1} \&$ Noorasiah Sulaiman ${ }^{1}$ \\ ${ }^{1}$ School of Economics, Faculty of Economics and Management, Universiti Kebangsaan Malaysia, Bangi, \\ Malaysia \\ Correspondence: Rahmah Ismail, School of Economics, Faculty of Economics and Management, Universiti \\ Kebangsaan Malaysia, 43600 Bangi, Selangor, Malaysia. Tel: 60-3-8921-3742. E-mail: rahis@ukm.my
}

\author{
Received: June 24, 2013 Accepted: December 13, 2013 Online Published: January 27, 2014 \\ doi:10.5539/ass.v10n3p221 URL: http://dx.doi.org/10.5539/ass.v10n3p221
}

\begin{abstract}
In modern living, the participation of female in the labor market is becoming essential for development economy. The higher educational attainment among females makes it easier for them to find jobs and to be involved in the labor market. Nevertheless, the participation of women in the labor market is less prevalent than for men, especially for married women, where family responsibilities and household chores become obstacles for them. This paper attempts to identify the determinants of married women's participation in the labor market based on 3,520 data collected in 2011 through a field survey. The results from this study show that educational attainment, women's age and number of children are major determinants of the supply of married women labor. In contrast, husbands' wage and own wage are insignificantly determined the supply of married women labor in this study.
\end{abstract}

Keywords: married women, female labor supply, educational attainment, children

\section{Introduction}

In modern living, the participation of female in the labor market is becoming more important for development economy, especially for a fast growing country. The robustness of the female labor force will promote economic development, which, in turn, will change the labor market conditions. The studies on the supply of female labor have been done by many researchers (Blundell, Ham \& Meghir, 1987; Arellano \& Meghir, 1992; Nakamura \& Nakamura, 1994; Eissa \& Liebman, 1996; Greenwood et al., 2005). In many countries, especially the developing economies, the participation of female employment has increased, in terms of quantity and job categories. This change shows a transition in the labor market structure, which indicates transformation in the composition and the participation rate of female labor. The larger participation rate by women in the labor workforce of economic sectors is a result of improvement in their educational level of attainment, whereby their involvement at the professional level has significantly increased.

As the participation rate of female labor attribute to several reasons, an investigation of determinants of female labor supply is actually essential, as they are important for policy design and the further benefits of females. In particular, we need to understand how female labor responds to the market wage, as wages will determine their family wellbeing, especially for a single parent. In the studies of labor supply, education has positively affected the possibility of female labor to enter the job market. The substantial effect of larger supply of female labor is on the dynamic ratio between average earnings of female and male. The results from several studies indicated that in 1960s and 1970s, a larger entrance of female labor with low skills and lack of working experience lead to deterioration in the labor quality, and, hence, lower labor productivity (Smith \& Ward, 1989; Goldin, 1989; 1990; O’Neil \& Polachek, 1993). This resulted an increase in the ratio of average earnings is remained constant during the two decades.

The choice of females to take part in the labor workforce is usually dominated by the household-decision process. In other words, the decision of whether woman work or not work, especially those who are married will be decided by the members of the household, particularly by adult males. Although working woman will generate income to the family as it will support expenditures increased and benefits of the household, working outside is actually led to a lesser time-spending with children and a household-chore. This will reduce a household-benefit. Thus, the decision of woman whether work or stay at home is determined by the collective utility of the household and the market wage is only as an economic incentive. Apart from that, the rate of participation among females to enter the labor market workforce is always influenced by several main factors. These are the 
presence of young children or children with disabilities, technology enhancement and discrimination of gender.

Few studies have observed the relationships between the supply of female labor and the process of decision by the household (Francois, 1998; Basu, 2006; Atal, 2010). Study by Atal (2010) discovered that the participation of female in labor workforce is decided by the household and the distribution of power is formed endogenously among the household members. The supply of female labor explains that the contribution of women income to their families will determine the distribution of power. The more she gains, the more her power increases in the household as meaning to say that she has more freedom to do an outside job.

In Malaysia, even though the participation of female labor in all economic sectors is increasing over years, their rate of participation is still low. The statistics show that the participation of female employment has not changed significantly over the last three decades and it remains at a range from 44 to $48 \%$ yearly. In terms of age group, the rate has decreased significantly for the group of 35-44 years. The participation of female in employment has decreased from 58 to $50 \%$ for the group of 45-54 years and yet decreased to only $25 \%$ for the group of 55-64 years (DOS, 2011). The female employment is relatively below than $50 \%$ out of the total employment.

Based on the discussions above, this paper attempts to examine the factors that determine supply of married women labor in Malaysia. This paper is formed as follows: Section two, discusses the literature of the past studies pertaining determinants of the female labor supply. Section three, outlines the methodology, which describes data collection, measures, variables, model specification, and descriptive statistics of the study. Section four, provides the results of the study by discussing factors in determining the supply of married women labor in Malaysia. Finally, the last section provides the summary and conclusion.

\section{Literature Review}

In general literature, education has a strong correlation with the economic growth, which, in turn, it will affect the pattern of supply in the labor market. The positive outcomes of education on the supply of labor market are obtained by many studies. For instance, an increase in level of educational attainment has positively affects an increase in labor supply in rural farm in Ghana and in agricultural sector in Sudan (Jolliffe, 2004; Babikir \& Babiker, 2007). More specifically, it has increased female labor supply of an urban labor markets in Sudan (Maglad, 1998). These findings of the studies actually supports the theory of human capital that the relationship between education and labor supply is highly correlated, which is, higher educational level is positively correlated with a higher potential of income earnings.

Previous studies have examined the factors that determine the supply of women labor. Most of the findings of female labor supply studies are supported by the theory of female labor supply, particularly the decision of whether to work or stay at home. By hypothesizing the value of time, the participation of female to work is positively correlated with the value qualities of a marriage. If the women have high value qualities in their marriage, their possibility to work is lesser (Grossbard-Shechtman \& Neuman, 1988).

In a recent study by Hazan and Maoz (2010) on the women choice to work shows that the pattern of workforce is extensive among the women in the United States in the 1960s and 1970s. During the periods, the women choose to join the labor workforce at an early stage of their life although the wage is sufficiently low. Most of studies on the female labor supply analyses females' characteristics especially when dealing with the house-task. The studies identified that great relationship occurs between supply of female labor and the size of the families, including age of the children. Furthermore, the husbands' characteristics, as well as their educational attainment and returns, will also influence the supply of female labor. However, it is different for unmarried female, educational attainment and wage rate are the more important characteristics in determining their labor supply. The similar study also observes employment of married women and the reason of married women to joint in the labor workforce is still unspecified, except obtained the result of wives' hours of work is relatively limited (Olivier, 2005).

As for traditional role of gender, woman is observed as supporting in terms of income to the family and particularly, their participation in the workforce has an adverse impact with their spouse's wages. Study by Saget (1999) indicates two prominent results. First, elasticity of wage of married woman is approximated to be positive. Second, husband's income (as he is head of the household) is not significant and has an adverse impact with the probability of female labor supply. This indicates that the supply of Hungarian female labor is not determined by income of their husband and the household. However, this result contrasts with result of the Canadian wives supply which highly related to the change in their husbands' wages during the 1980s (Morissette \& Hou, 2008).

As the increased in female employment is due to increase in their educational attainment, the study found that 33 percent of an increase in female employees is contributed by education, while another 40 percent is observed by 
the households' characteristics and the remaining percentage is unexplained factors (Eckstein \& Lifshitz, 2009).The study further extended that the unexplained factors is attributed to the preferences of working or to face the costs of childcare and households expenses. In the particular study, the work behavior of women largely depends on their wages and their husband's wages, and, the elasticity of the labor market supply (Gomez \& Vazquez, 2010). Moreover, the elasticity of female labor supply had a rather sharp decrease between 1990 and 2000 , which representing women are increasingly attached to the labor market.

Another study was developed a model of female labor supply by taking into account the factor of inter-temporal. Concerning to this analysis, under uncertainty labor will optimize their job search activity as well (Arellano \& Meghir, 1992). This contrast from many previous studies that disregard the factor of inter-temporal in the model of supply female labor (Heckman, 1974; Hausman, 1980; Heckman \& MaCurdy, 1980; Cogan, 1981; Blundell \& Walker, 1986; Altonji, 1986). Furthermore, the participation of female labor has been in S-shaped, in which, slow at the first stage, fast in the second stage, and finally, stable due to the women with young children decide to work.

The recent circumstance of participation among female to joint in the workforce is based on the justification that competency is relatively important among the women and spending time with children is also essential for the children futures (Fogli \& Veldkamp, 2008). The study was extended to investigate the process of the transition of women into the workforce. The benefit of maternity will improved as employment of married women increased. Thus, the rate of participation rise faster and overall growth of participation rates is also increased.

The importance of structure of the family on the supply of female labor is also taken into consideration (Newman \& Gertler, 1994). The structure of the family is found positively correlated to the household income and female labor supply in Peru. Several studies have shown that the age of children is significantly influenced the supply of married women labor (Gronau, 1973; Rosenzweig \& Wolpin, 1980; Schultz, 1990). From the study, the effect on the supply of female labor is negative and it is actually larger for children at the younger age (below 6 years old) and an adverse result can be seen for children at the older age (above 12 years old) (Augrist \& Evans, 1996).

Based on the results from past studies, most researches agreed that the working hours of mother will reduce as they have children, whereas it is insignificant for father. This is similar with the results obtained for Malaysia, that show the children below age of 6 years old and children in the schooling age is also reduced hours of work of married women in the sub sector of handicraft (Rahmah \& Fatimah, 1999). Another study pertaining to Malaysia shows the effect of wives' incomes on the household income disparity in Peninsular Malaysia from period 1976 to 1988 . The study reveals that the wives' incomes assist to reduce income disparity among the households in Malaysia (Shahina \& Julie, 2004).

Another factor decreases hours of work by female labor is due to the health constraints and care commitments. Among an elderly American worker who resigned from 1992 to 2000, 13\% respond that they will stay working if they can reduce their working hours (Penner et al., 2002). Similarly, about 7\% of workers in Sweden in age 50 and above claimed that by shortening hours of work they may continue their present job until the age of official retirement. This because by shortening hours of work they would overcomes physical and health problem (Wadensjo, 2008).

In general, the rate of female labor participation has increased since after the Second World-War II as women reduced in having child (Coleman \& Pencavel, 1993; Schultz, 1978; Rosenzweig \& Wolpin, 1980). The results from the study in Mexico (Wong \& Levine, 1992) and in the United States (Tienda \& Glass, 1985) also support the findings of an expansion in female labor participation will lower the number of children in the families. More specifically, if the opportunity of women in aged 21 to 35 years in getting at least two child reduced by $18 \%$, this will increase female labor force participation rate by $21 \%$ (Augrist \& Evans, 1996).

\section{Theoretical Framework, Methodology and Model Specification}

The decision to work among females is very much dependent on their dual role and the allocation of times between these two tasks. A woman can choose between working at home to do household production, such as taking care of the children; doing household chores, such as cooking or washing; or she can choose to do market work by offering her services in the labor market to get paid, which can be used for buying goods and services. A labor supply model for married females assumes that the female still lives with her husband, has at least one child and she is the best person to look after her child. Based on Ribar (1992), Connelly (1992), Michalopoulos et al. (1991), Powel (1997), Kimmel (1998), and Blau and Robins (1988), utility maximization can be written as follows:

$$
U=U(X, L, Q)
$$

Where, $U$ is utility, $X$ is consumption of goods and services, $L$ is leisure time and $Q$ is childcare quality. The 
utility maximization of equation (1) is subjected to these three constraints:

$$
\begin{gathered}
H W+V=X+P_{C} T_{C} \\
H+T_{M}+L=1 \\
T_{M}+T_{C}+1
\end{gathered}
$$

Where, $\mathrm{H}$ is female hours of work, $\mathrm{W}$ is female wage rate, $\mathrm{V}$ is household non-labor income, $\mathrm{P}_{\mathrm{c}}$ is child-bearing cost, $T_{C}$ is time spent for child care, $T_{M}$ is time spent for working in the market. Solving equation (1) subjects to three constraints will produce the equation below:

$$
\frac{U_{L}}{U_{X}}=W=\frac{U_{0}}{U_{X}}\left(Q_{1}-Q_{2}\right)=P_{C}
$$

This equation shows that a woman will participate in the labor market when the rate of marginal substitution between leisure and goods is equal to the wage rate, hence equal to the net benefit from childcare services quality. Therefore, the female labor supply function can be written as:

$$
H=h\left(W, P_{C}\right)
$$

Other variables can be added into equation (6) to include female characteristics and other related variables. The general function is written as follows:

$$
H=h\left(W, P_{C}, Z i\right)
$$

In this paper, female labor supply is measured by a dummy variable as 1 if they are working and zero if they are not working. As the dependent variable is categorical, the logistic regression approach is used in the estimation.

In general, logistic regression is applied to evaluate the functional relationship between the dependent variables, which is qualitative and the independent variables, both quantitative and qualitative variables. The dependent variable with categorical is used, whereby, the value 1 denotes if a head of household is working and 0 denotes if a head of household is not working. Therefore, the model is estimated in logistic binomial form. The model used is as follows:

$$
P_{i}=1\left(1+e^{-z}\right)
$$

Where $P_{i}$ is the probability of workers having been mobile $(Y=1)$. The probability to choose the other is ( $\left.Y=0\right)$ written as:

$$
\left(1-P_{i}\right)=1 /\left(1+e^{-z}\right)
$$

Therefore, the probability of a worker changing jobs is:

$$
e^{z}=P_{i} /\left(1-P_{i}\right)
$$

The model is then transformed to a logarithm model to produce the equation:

$$
z_{i}=\ln \left(P_{i} /\left(1-P_{i}\right)=\operatorname{lnezi}=\beta_{0}+\beta_{1} X_{1}+\beta_{2} X_{2}+\ldots .+\beta_{n} X_{n}\right.
$$

The estimation of the logistic model utilizes the likelihood ratio test (LRT) as an indicator for fitness of the model and the t-test for identifying the significant of the parameters. The estimation model for this study is as follows:

$$
\begin{gathered}
L S_{i}=\beta_{0}+\beta_{1} H W_{i}+\beta_{2} F W_{i}+\beta_{3} F E D U_{i}+\beta_{4} F A G E_{i}+\beta_{5} N L Y_{i}+\beta_{6} N U M C_{i} \\
+\beta_{7} G L O B_{i}+\mu_{i}
\end{gathered}
$$


Where, LS is female labor supply status whether working or not working, HW is husband's monthly wage, FW is female's monthly wage, FEDU is female level of education, FAGE is female's age, NLY is family non-labor income. NUMC is the number of children and GLOB is female's perception on the effect of globalization on their work opportunities and $\mathrm{i}$ is individuals.

\section{Source of Data}

The analysis is based on the data collected from the field survey in 2011 . The survey covered 4,000 households in Peninsular Malaysia, which were chosen using stratified random sampling; however, only 3,885 questionnaires were completed. The data included information on heads of households, spouses, families, background of education and background of employment. Since the main objective of this paper is to look at the married women labor supply decision, the wives' data are used in the analysis, which comprise 3,520 married women. The study only covers the states in Peninsular Malaysia due to constraints of time and finances. The total sample in each state is based on the following formula:

Sample in each state $=\frac{\text { TotalPopulationineachstate }}{\text { TotalPopulationinMalaysia }} \times 4000$

Table 1. Population and sample

\begin{tabular}{|c|c|c|}
\hline State & Population, 2010 (million) & Total Sample \\
\hline \multicolumn{3}{|l|}{ Northern Region } \\
\hline Kedah & 2.04 & 355 \\
\hline Perak & 2.44 & 425 \\
\hline Perlis & 0.25 & 43 \\
\hline Pulau Pinang & 1.6 & 279 \\
\hline \multicolumn{3}{|l|}{ Middle Region } \\
\hline Melaka & 0.79 & 138 \\
\hline Negeri Sembilan & 1.03 & 179 \\
\hline Selangor & 5.31 & 924 \\
\hline Wilayah Persekutuan Kuala Lumpur & 1.7 & 296 \\
\hline \multicolumn{3}{|l|}{ Southern Region } \\
\hline Johor & 3.46 & 602 \\
\hline \multicolumn{3}{|l|}{ Eastern Region } \\
\hline Kelantan & 1.67 & 291 \\
\hline Pahang & 1.57 & 273 \\
\hline Terengganu & 1.12 & 195 \\
\hline Malaysia & 22.98 & 4000 \\
\hline
\end{tabular}

Table 2 presents the profiles of the respondents, which are categorized into seven components. The majority of respondents is aged less than 45 years old and holds secondary level of education. Their distribution in the public and private sectors is almost equal, and very few of them work in multinational corporations. Almost half of the respondents work as full-time workers and are involved in the services sector. Even though the majority of them have been working for more than 30 years, almost half receive a monthly wage of less than RM1000. 
Table 2. Profile of respondents

\begin{tabular}{|c|c|c|}
\hline Characteristics & Total & Percentage \\
\hline \multicolumn{3}{|l|}{ Age } \\
\hline$<25$ & 158 & 4.5 \\
\hline $26-35$ & 995 & 28.3 \\
\hline $36-45$ & 1138 & 32.3 \\
\hline $46-55$ & 1005 & 28.6 \\
\hline$>56$ & 224 & 6.3 \\
\hline Total & 3520 & 100.0 \\
\hline \multicolumn{3}{|c|}{ Level of education } \\
\hline Primary & 406 & 11.5 \\
\hline Secondary & 1794 & 51.0 \\
\hline Diploma/STPM & 674 & 19.1 \\
\hline Degree & 614 & 17.4 \\
\hline Others & 32 & 0.9 \\
\hline Total & 3520 & 100.0 \\
\hline \multicolumn{3}{|l|}{ Job sector } \\
\hline Public & 996 & 28.3 \\
\hline Private & 759 & 21.6 \\
\hline Multinational & 59 & 1.7 \\
\hline Others & 1706 & 48.5 \\
\hline Total & 3520 & 100.0 \\
\hline \multicolumn{3}{|l|}{ Job-status } \\
\hline Full-time & 1618 & 46.0 \\
\hline Part-time & 66 & 1.9 \\
\hline Self-employed & 134 & 3.8 \\
\hline Others & 1702 & 48.4 \\
\hline Total & 3520 & 100.0 \\
\hline \multicolumn{3}{|c|}{ Job in economic sector } \\
\hline Services & 1611 & 45.8 \\
\hline Manufacturing & 151 & 4.3 \\
\hline Agriculture & 48 & 1.4 \\
\hline Mining & 1 & 0.0 \\
\hline Construction & 10 & 0.3 \\
\hline Others & 1699 & 48.3 \\
\hline Total & 3520 & 100.0 \\
\hline \multicolumn{3}{|c|}{ Working experience } \\
\hline$<10$ years & 945 & 26.8 \\
\hline $11-20$ years & 555 & 15.8 \\
\hline $21-30$ years & 287 & 8.2 \\
\hline$>30$ years & 1734 & 49.2 \\
\hline Total & 3520 & 100.0 \\
\hline \multicolumn{3}{|l|}{ Total income } \\
\hline$<1000$ & 1683 & 47.8 \\
\hline $1001-2000$ & 633 & 18.0 \\
\hline $2001-3000$ & 504 & 14.3 \\
\hline $3001-4000$ & 397 & 11.3 \\
\hline $4001-5000$ & 158 & 4.5 \\
\hline$>5000$ & 145 & 4.1 \\
\hline Total & 3520 & 100.0 \\
\hline
\end{tabular}

Source: Field Survey, 2011 
Table 3 presents descriptive statistics of the variables used in the model of labor supply. The mean of monthly wage for the husbands is RM3275.96 and for wives is RM1985.75. The mean years of schooling for female are11.8 years, 51 percent received secondary education and 37 percent received tertiary education. On average, females are 41 years old and have about three children. Most females highly agreed with the effect of globalization on their participation in labor force.

Table 3. Descriptive statistics of variables

\begin{tabular}{lrr}
\hline Variables & Mean & Standard deviation \\
\hline Husband's wage (RM) & 3275.96 & 2932.650 \\
Own wage (RM) & 1985.75 & 1901.984 \\
Years of schooling & 11.80 & 3.154 \\
Secondary education & 0.51 & 0.500 \\
Tertiary education & 0.37 & 0.482 \\
Age & 40.93 & 19.839 \\
Non-labor income (RM) & 171.56 & 58.649 \\
Number of children & 2.60 & 1.737 \\
Perception on the effect of globalization & 5.48 & 1.164 \\
\hline
\end{tabular}

The results from the estimation of the logistic regression model are shown in Table 4 . The $\mathrm{R}^{2}$ is between 0.373 and 0.482 , which implies that about $37.3 \%$ to $48.2 \%$ of the variation in the dependent variables can be explained by the independent variables. The results show that four variables significantly influence the decision of married women to work, namely, years of schooling, age, secondary level of education and tertiary level of education, as noted in Table 4. Years of schooling and age are found to have a positive impact on the decision of married women and are significant at 5\%. The marginal effects show that a one-year increase in school years increases the possibility of being in the labor market by $13.5 \%$. In contrast, an increase of one year in the age of the married women will reduce the probability of working by $4.3 \%$. Married women with secondary and tertiary education are more likely to be working compared to those with primary education. The number of children also has a negative impact on the supply of married women labor by reducing the probability of being in the labor market by about $16.2 \%$ to $17.2 \%$ with the addition of one child. 
Table 4. Logistic regression estimates

\begin{tabular}{|c|c|c|c|c|c|c|}
\hline \multirow[t]{2}{*}{ Variables } & \multicolumn{3}{|c|}{ Level of education } & \multicolumn{3}{|c|}{ Years of schooling } \\
\hline & Coefficients & $\begin{array}{r}\operatorname{Exp} \\
(\mathrm{B})\end{array}$ & $\begin{array}{r}\text { Marginal } \\
\text { effect }\end{array}$ & Coefficients & $\begin{array}{r}\text { Exp } \\
(\mathrm{B})\end{array}$ & $\begin{array}{r}\text { Marginal } \\
\text { effect }\end{array}$ \\
\hline Constant & $\begin{array}{r}1.117 \\
(4.663)\end{array}$ & 0.966 & 0.2319 & $\begin{array}{r}-1.1329 \\
(7.168)\end{array}$ & 0.000 & 0.2693 \\
\hline Husband's wage & $\begin{array}{r}0.001 \\
(0.000)\end{array}$ & 1.000 & 0.000208 & $\begin{array}{l}0.001 \\
(0.00)\end{array}$ & 1.000 & 0.000238 \\
\hline Own Wage & $\begin{array}{r}0.001 \\
(0.000)\end{array}$ & 0.036 & 0.000208 & $\begin{array}{r}0.001 \\
(0.000)\end{array}$ & 1.000 & 0.000238 \\
\hline Years of schooling & & & & $\begin{array}{r}0.568 \\
(0.230)^{* *}\end{array}$ & 1.765 & 0.1350 \\
\hline Secondary education & $\begin{array}{r}3.337 \\
(1.992)^{*}\end{array}$ & 1.045 & 0.6928 & & & \\
\hline Tertiary education & $\begin{array}{r}3.102 \\
(1.896)^{*}\end{array}$ & 1.145 & 0.6439 & & & \\
\hline Age & $\begin{array}{r}-0.135 \\
(0.075)^{*}\end{array}$ & 1.000 & -0.0280 & $\begin{array}{r}-0.182 \\
(0.080)^{* *}\end{array}$ & 1.199 & -0.0433 \\
\hline Non-labor income & $\begin{array}{l}0.0001 \\
(0.000)\end{array}$ & 2.286 & 0.000021 & $\begin{array}{l}0.0001 \\
(0.000)\end{array}$ & 1.000 & 0.000024 \\
\hline Number of children & $\begin{array}{r}-0.827 \\
(0.464)^{*}\end{array}$ & 0.917 & -0.1718 & $\begin{array}{r}-0.682 \\
(0.495)\end{array}$ & 1.977 & -0.1621 \\
\hline $\begin{array}{l}\text { Perception on the effect of } \\
\text { globalization }\end{array}$ & $\begin{array}{l}-0.087 \\
(0.492)\end{array}$ & 3.055 & -0.0181 & $\begin{array}{r}-0.186 \\
(0.230)\end{array}$ & 0.831 & -0.0442 \\
\hline Negelkerke R & & 0.373 & & & 0.482 & \\
\hline $\mathrm{N}$ & & 3520 & & & 3520 & \\
\hline
\end{tabular}

Notes: Figures in parentheses are standard error. Marginal effect is calculated for logistic regression using the formula $\frac{\partial p}{\partial x_{i}}=f(\bar{Z}) \hat{\beta}_{i}$ where $(\bar{Z})=\frac{e^{-\bar{Z}}}{\left(1+e^{-\bar{Z}}\right)^{2}}$. For the dummy variables, $\partial \mathrm{x}$ refers to discrete changes from 0 to 1.

*significant at $10 \%$,**significant at $5 \%$.

\section{Conclusion}

Women's participation in the labor market is constrained by many characteristics of the family due to their dual roles. The labor market theory proposes, that, in general, the labor supply is determined by own wage, spouse wage and non-labor income. However, this study shows that the important determinants are years of schooling and age. Years of schooling positively affect the supply of married women labor whereas age has an adverse effect. Wages, either own or husband's wage, is not proven to be significant from this study. The importance of education is supported by the more likely effect of women with secondary and tertiary education to be in the labor market compared to those with primary and no schooling.

The results from this study have several policy implications. Since wage is not a prime determinant of married women labor supply, but education is, women must attain higher education to gain benefit from the labor market. The number of children is another important obstacle for married women to be in the workforce, therefore childcare facilities must be provided in the workplace to assist women. As far as the Government is concerned, 
women's participation in the workforce is most welcome to obtain benefit, especially those with higher level of education.

\section{Acknowledgements}

We would like to thank the Universiti Kebangsaan Malaysia for providing us research grant to carry-out this study. Many thanks also to our research assistants in helping us to complete this study.

\section{References}

Altonji, J. G. (1986). Inter-temporal substitution in labor supply: Evidence from micro data. Journal of Political Economy, 94(2), 176-215. http://dx.doi.org/10.1086/261403

Arceo, G., Eva, O., \& Raymundo, M. C. V. (2010). Labor supply of married women in Mexico: 1990-2000. Series Documentos de Trabajo, No. XVI-2010, Centro de Estudios Economicos, El Colegio de Mexico, A. C.

Arellano, M., \& Meghir, C. (1992). Female labour supply and on-the-job search: An empirical model estimated using complementary data sets. Review of Economic Studies, 59(3), 537-559. http://dx.doi.org/10.2307/2297863

Atal, V. (2010). Say at home, or stay at home? A theory of female labor supply. Retrieved from http://ssrn.com/abstract=1807045

Augrist, J. D., \& Evans, W. N. (1996). Children and their parents' labour supply: Evidence from exogenous variation in family size. NBER Working Paper No. 5778 (September).

Babikir, O. M., \& Babiker, B. I. (2007). The determinants of labour supply and demand in irrigate agriculture: A case study of the Gezira Scheme in Sudan. African Development Review, 19(2), 335-349. http://dx.doi.org/10.1111/j.1467-8268.2007.00164.x

Basu, K. (2006). Gender and say: A model of household behaviour with endogenously- determined balance of power. The Economic Journal, 116(511), 558-580. http://dx.doi.org/10.1111/j.1468-0297.2006.01092.x

Blau, D., \& Robins, P. (1988). Child-care costs and family labor supply. The Review of Economics and Statistics, 70(3), 374-381. http://dx.doi.org/10.2307/1926774

Blundell, R. W., \& Walker, I. (1986). A life cycle consistent empirical model of labour supply using cross-section data. Review of Economic Studies, 53, 539-558. http://dx.doi.org/10.2307/2297605

Blundell, R., Ham, W. J., \& Meghir, C. (1987). Unemployment and female labour supply. Economic Journal, 97 , 44-64. http://dx.doi.org/10.2307/3038229

Bourguignon, F., \& Chiappori, P. A. (1992). Collective models of household behavior: An introduction. European Economic Review, 36, 355-364. http://dx.doi.org/10.1016/0014-2921(92)90091-A

Bourguignon, F., \& Chiappori, P. A. (1994). The collective approach to household behavior. In R. Blundell, I. Preston, \& I. Walker (Eds.), The Measurement of Household Welfare. Cambridge University Press, Cambridge. http://dx.doi.org/10.1017/CBO9780511598968.003

Carlin, P. S., \& Lennart, F. (1997). Do children affect the labor supply of Swedish men? Time-diary vs. survey data. Labour Economics, 2, 167-183. http://dx.doi.org/10.1016/S0927-5371(96)00011-5

Cogan, J. (1981). Fixed costs and labor supply. Econometrica, 49(4), 945-964. http://dx.doi.org/10.2307/1912512

Coleman, M. T., \& Pencavel, J. (1993). Trends in market work behaviour of women since1940. Industrial and Labour Relations Review, 46, 653-676. http://dx.doi.org/10.2307/2524310

Connelly, R., \& Kimmel, J. (2003). The effect of child care costs on the employment and welfare recipiency of single mothers. Southern Economic Journal, 69(3), 498-519. http://dx.doi.org/10.2307/1061691

Department of Statistics. (2011). Labour Force Survey Report, Third Quarter 2011, DOS, Putrajaya.

Eckstein, Z., \& Lifshitz, O. (2011). Dynamic female labor supply. Econometrica, 79(6), 1675-1726. http://dx.doi.org/10.3982/ECTA8803

Eissa, N., \& Liebman, J. (1996). Labour supply response to the earned income tax credit. Quarterly Journal of Economics, 111(2), 605-637. http://dx.doi.org/10.2307/2946689

Euwal, R. (1999). Female labour supply, flexibility of working hours and job mobility in the Netherlands. Discussion Paper, No. 83, RePec: iza:izadps:dp83. 
Fogli, A., \& Veldkapm, L. (2008). Nature or nurture? Learning and female labour force dynamics, NBER Working Papers 14097.

Fogli, A., \& Veldkapm, L. (2011). Nature or nurture?: Learning and the geography of female labor force participation. Econometrica, 79(4), 1103-1138. http://dx.doi.org/10.3982/ECTA7767

Francois, P. (1998). Gender discrimination without gender difference: Theory and policy responses. Journal of Public Economics, 68(1), 1-32. http://dx.doi.org/10.1016/S0047-2727(97)00061-3

Goldin, C. (1989). Life Cycle Labor force participation of married women, historical evidence and implications. Journal of Labor Economics, 7, 20-47. http://dx.doi.org/10.1086/298197

Goldin, C. (1990). An economic history of American women in understanding the gender gap. Oxford University Press, New York.

Greenwood, J., Seshadri, A., \& Yorukoglu, M. (2005). Engines of liberation. Review of Economic Studies, 72(1), 109-133. http://dx.doi.org/10.1111/0034-6527.00326

Gronau, R. (1973). The effect of children on the housewife's value of time. Journal of Political Economy, 81(2), 168-199. http://dx.doi.org/10.1086/260160

Grossbard-Shechtman, S. A., \& Neuman, S. (1988). Women labor supply and marital choice. The Journal of Political Economy, 96(6), 1294-1302. http://dx.doi.org/10.1086/261588

Hausman, J. (1980). The effect of wages, taxes and fixed costs on women's labour force participation. Journal Public Economics, 14, 162-194. http://dx.doi.org/10.1016/0047-2727(80)90039-0

Hausman, J. (1981). Labour supply: How taxes affect economics behavior. In H. Aaron, \& J. Pechman (Eds.), Tax and the Economy. Brooking Institution, Washington, D.C.

Hazan, M., \& Maoz, Y. D. (2010). Women's lifetime labour supply and labour market experience. Journal of Economic Dynamics and Control, 34, 2126-2140. http://dx.doi.org/10.1016/j.jedc.2010.06.012

Heckman, J. (1974). Shadow prices, market wages and labor supply. Econometrica, 42(4), 679-694. http://dx.doi.org/10.2307/1913937

Heckman, J. (1994). What has been learnt about labour supply in the past twenty years? American Economic Review, 83(2), 116-121.

Heckman, J. J., \& MaCurdy, T. E. (1980). A life cycle model of female labour supply. Review of Economic Studies, 47, 47-74. http://dx.doi.org/10.2307/2297103

Jolliffe, D. (2004). The impact of education in rural Ghana: Examining household labour allocation and returns on and off the farm. Journal of Developing Economics, 73, 287-314. http://dx.doi.org/10.1016/j.jdeveco.2003.02.002

Kimmel, J. (1998). Child care costs as a barrier to employment for single and married mothers. The Review of Economics and Statistics, 80(2), 287-299. http://dx.doi.org/10.1162/003465398557384

Layard, R., Barton, M., \& Zabalza, A. (1980). Married women's participation and hours. Economica, 47, 51-72. http://dx.doi.org/10.2307/2553167

Lehrer, E. L. (1992). The impact of children on married women's labour supply: Black-White differentials revisited. Journal of Human Resources, 27(3), 422-444. http://dx.doi.org/10.2307/146170

Lundberg, S. J. (2008). Gender and household decision-making. In F. Bettio (Ed.), Frontier in Gender Economics. Routledge: London. http://dx.doi.org/10.4324/9780203927694.ch7

Maglad, N. A. (1998). Female labour supply in Sudan. African Economic Research Consortium (Special Paper $30)$.

Michalopoulos, C., \& Robins, P. K. (2002). Employment and child-care choices of single-parent families in Canada andthe United States. Journal of Population Economics, 15(3), 465-493. http://dx.doi.org/10.1007/s001480100099

Morissette, R., \& Hou, F. (2008). Does the labour supply of wives respond to husbands' wages? Canadian evidence from micro data and grouped data. Canadian Journal of Economics, 41(4), 1186-1210. http://dx.doi.org/10.1111/j.1540-5982.2008.00500.x

Nakamura, A., \& Nakamura, M. (1994). Predicting female labor supply: Effects of children and recent work experience. Journal of Human Resources, 29(2), 304-327. http://dx.doi.org/10.2307/146100 
Newman, J., \& Gertler, P. (1994). Family productivity, labour supply and welfare in a Low Income Country. The Journal of Human Resources, 29, 989-1026. http://dx.doi.org/10.2307/146132

O'Neil, J., \& Polachek, S. (1993). Why the gender gap in wages narrowed in the 1980s. Journal of Labor Economics, 11(1), 205-225. http://dx.doi.org/10.1086/298323

Olivier, D. (2005). Collective female labour supply: Theory and application. Institute for the Study of Labor (IZA), IZA Discussion Paper No. 1506.

Penner, R. G., Perun, P., \& Steurle, E. (2002). Legal and institutional impediments to partial retirement and part-time work by older workers. Washington D.C. The Urban Institute. Retrieved from http:www.urban.org/uploadedPDF/410587_SlopanFinal.pdf

Powell, L. M. (1998). Part-time versus full-time work and childcare costs: Evidence for married mothers. Applied Economics, 30(4), 503-511. http://dx.doi.org/10.1080/000368498325769

Rahmah, I., \& Fatimah, S. (1999). Women's education and household activities. In M. Ismail \& A. Ahmad (Eds.), Women and Work: Challenges in Industrializing Nations (pp. 27-56). London: Asean Academic Press.

Ribar, D. (1992). Child care and the labor supply of married women. Journal of Human Resources, 27(1), 134-165. http://dx.doi.org/10.2307/145915

Rosenzweig, M., \& Wolpin, K. I. (1980). Life cycle labour supply and fertility: Evidence from household models. Journal of Political economy, 88, 328-348. http://dx.doi.org/10.1086/260868

Saget, C. (1999). The determinants of female labour supply in Hungary. Economics Transition, 7(3), 575-591. http://dx.doi.org/10.1111/1468-0351.00026

Schults, T. P. (1990). Testing the Neo-classical model of family labour supply and fertility. Journal of Human Resources, 25, 599-634. http://dx.doi.org/10.2307/145669

Shahina, A., \& Julie, D. (2004). The impact of wives' earnings on earnings inequality among married-couple households in Malaysia. Journal of Asian Economics, 15(1), $49-70$. http://dx.doi.org/10.1016/j.asieco.2003.12.002

Smith, J. P., \& Ward, M. (1989). Women in the labor market and in the family. Journal of Economic Perspectives, 3, 9-23. http://dx.doi.org/10.1257/jep.3.1.9

Tienda, M., \& Glass, J. (1985). Household structure and labour force participation of Black, Hispanics and White Mothers. Demography, 22, 381-394. http://dx.doi.org/10.2307/2061067

Vermeulen, F. (2002). Collective household models: Principles and main results. Journal of Economic Surveys, 16(4), 533-564. http://dx.doi.org/10.1111/1467-6419.00177

Wadensjo, E. (2008). Work and pension in Sweden. European Papers on the new welfare: The counter-ageing society, 9, 104-112.

Wong, R., \& Levine, R. (1992). The effect of household structure on women's economic activity and fertility: Evidence from recent mother in urban Mexico. Economic Development and Cultural Change, 41, 89-102. http://dx.doi.org/10.1086/451997

\section{Copyrights}

Copyright for this article is retained by the author(s), with first publication rights granted to the journal.

This is an open-access article distributed under the terms and conditions of the Creative Commons Attribution license (http://creativecommons.org/licenses/by/3.0/). 